\title{
EFFECT OF SOME PULSING SOLUTIONS AND COLD STORAGE PERIODS ON THE PHYSIOLOGICAL CHARACTERISTICS AND CHEMICAL CONSTITUENTS OF Rosa hybrida, L. cv. FIRST RED FLOWERS
}

\author{
E. M. Badawy, M. M. M. Hussein and Nermeen T. Shanan. \\ Ornamental Horticulture Department, Faculty of Agriculture, Cairo University, Egypt.
}

\section{ABSTRACT}

This study was carried out at the Ornamental Horticulture Department, Faculty of Agriculture, Cairo University, during the two successive seasons of 2004 and 2005 to investigate the effect of pre-storage pulsing treatments and storage periods on the physiological characteristics and chemical constituents of rose flowers (Rosa hybrida L. cv. First Red). The base of stem flowers were pulsed with (1) distilled water for 30 minutes (Control), (2) Florrisant 600 at a concentration of 10000 ppm for 4 hours, (3) Florrisant 600 solution at a concentration of 5000 ppm for 4 hours, (4) $G A_{3}$ at a concentration of 20 ppm for 24 hours, (5) Kinetin at a concentration of $25 \mathrm{ppm}+8$-hydroxyquinoline (8-HQ) at 150 ppm for 24 hours, (6) Sucrose at a concentration of $2 \%+\mathrm{AgNO}_{3}$ at 1000 ppm for 30 minutes, or (7) $\mathrm{AgNO}_{3}$ at a concentration of $1000 \mathrm{ppm}$ for 30 minutes. After that, the flowers were stored at a temperature of $2^{\circ} C$ and a relative humidity $(\mathrm{RH})$ of $85-90 \%$, in cold storage rooms for periods of 7, 14, 21 or 28 days.

Most of the pulsing solutions decreased the rate of fresh weight loss, respiration rate of flowers, but increased the total soluble sugars and total soluble phenols contents in petals and leaves, the anthocyanins and carotenoids contents in the petals, as well as the total chlorophylls and carotenoids contents in the leaves. Pulsing in a solution containing 25 ppm kinetin +150 ppm 8-HQ for 24 hours gave the lowest rates of fresh weight loss and respiration, and the highest contents of total soluble sugars in the leaves, total soluble phenols in the petals and the leaves, anthocyanins and carotenoids in the petals.

The rate of fresh weight loss, and the contents of total soluble phenols in the petals and leaves were increased with increasing storage period. On the other hand, respiration rate, total soluble sugars in the petals and leaves, anthocyanins and carotenoids in the petals as well as total chlorophylls and carotenoids content in the leaves were decreased with increasing storage period.

A significant interaction was detected between the effects of pulsing solutions and storage periods on the rate of fresh weight loss, respiration rate, anthocyanins and carotenoids contents in the petals, as well as total chlorophylls and carotenoids contents in the leaves. Flowers pulsed with $25 \mathrm{ppm}$ kinetin + 150 ppm 8-HQ for 24 hours and stored for 14 days gave an insignificantly different respiration rate compared to the lowest values, and gave total soluble sugars in the petals and leaves, total soluble phenols in the petals and leaves, anthocyanins and carotenoids in the petals insignificantly different than the highest values recorded for each characteristic. So, it can be 
recommended that Rosa hybrida $\mathrm{cv}$. First Red could be stored for 14 days, at a temperature of $2^{\circ} \mathrm{C}$ and a relative humidity of 85-90\%, after pulsing in $25 \mathrm{ppm}$ kinetin +150 ppm 8-HQ for 24 hours, in order to maintain good physiological characteristics and chemical constituents of flowers.

Key words: Cold storage, pre-storage treatments, 8-hydroxyquinoline, 8-HQ, Florrisant 600, $\mathrm{GA}_{3}$, Kinetin, $\mathrm{AgNO}_{3}$, Rosa hybrida.

\section{NTRODUCTION}

I

Rosa hybrida belongs to family Rosaceae. The rose undoubtedly remains the queen of the cut flowers. The production of cut rose flowers in Egypt has become a growing industry, as more and more growers are expanding their businesses by growing cut flowers. However, it is important to understand that the harvesting stages, postharvest handling and marketing techniques significantly affect the quality and the longevity of the flowers.

The storage of cut flowers makes it possible to adjust the supply to market demands. Moreover, storage makes it possible to accumulate large quantities of plant material for a single shipment. This simplifies the management process. The storage of flowers effectively extends the sales season for such flowers as rose, gladiolus, and carnation. It is also important for flowers bound for export, since conditions found to be suitable for flower storage can be used during long-distance transportation by truck and by ship. While proper storage will ensure maximum longevity for most cut flowers, prolonged storage can result in decreased vase life. The objective is always to ensure excellent quality of flowers after storage, without loss in viability or development. This can be achieved, at least partly, by determining the suitable storage period under certain storage conditions (Sacalis, 1993). Many researchers investigated the effect of storage periods on cut flowers, such as Serrano et al. (1992) on rose cv. Visa flowers, Daj and Paul (1995) on Protea nerifolia cv. Pink Wink, Jones (1995) on Leucadendron cv. Silver Red and Bhattacharjee (2000) on rose cv. Raktagandha, , Palanikumar et al. (2000) on rose, Singh and Kumar (2000) on Phyllanthus emblica cv. Chakaiya, Mwangi et al. (2003) on rose cv. Golden Gate and Singh et al. (2004) on rose cv. Queen Elizabeth.

Many substances (silver nitrate, gibberellic acid, kinetin, ...etc.), in addition to several commercial products, are used in pulsing solutions to keep flower quality during storage by affecting morphological traits and bio-chemical processes. Silver nitrate $\left(\mathrm{AgNO}_{3}\right)$ increased total soluble sugars content in petals and consequently increased vase life of rose cv. Raktagandha (Bhattacharjee and De, 1998). Gibberellic acid prevented leaf chlorosis, which was the major postharvest disorder in many cut flowers such as Santonia cv. Golden Light flowers (Eason et al., 2001). Kinetin delayed the onset of climacteric ethylene production, decreased the level of ethylene production, delayed senescence, prolonged longevity and maintained quality of 'Dolce Vita' flowers (Wawrzynczak and Goszczynska, 2003). Some researcher tested commercial products as pulsing solutions. In this respect, Sytsema (1990) reported 
that Florissant-400 had a detrimental effect on the performance of Syringa vulgaris cv. Mme Florent Stepman flowers, whereas Ferrante et al. (1998) reported that Florrissant 400 increased vase life of Eucalyptus spp. Branches.

\section{MATERIALS AND METHODS}

This study was carried out at the Ornamental Horticulture Department, Faculty of Agriculture, Cairo University, during the two successive seasons of 2004 and 2005 with the aim of investigating the effect of pre-storage treatments and storage periods on the physiological characteristics and chemical constituents of rose flowers (Rosa hybrida, L. cv. First Red).

Rose flowers (Rosa hybrida, L. cv. First Red) were obtained from Floramix, a Commercial Farm in Kafr Hakim, Giza. The flowers were selected having a stem length of $80 \mathrm{~cm}$ and bearing four pairs of leaves on each stem. On $1^{\text {st }}$ November 2004 and 2005, the flowers were harvested at the mature bud stage in the early morning. The flowers were precooled (at $4^{\circ} \mathrm{C}$ for 6 hours) to remove the effect of high temperature in the field, then they were wrapped in Kraft paper in bunches, each containing 20 flower stems. The flowers were moved under dry conditions to the Laboratory within one hour, where they were unwrapped. The stem bases were then re-cut in air by removing about $3 \mathrm{~cm}$.

Two hundred and fifty two flowers were divided into seven groups (each consisting of 36 flowers), which received different pulsing treatments, by immersing the flower stems for different durations in buckets containing solutions prepared using different commercial products and chemicals, as follows:

1- Distilled water for 30 minutes.

2- Florrisant 600 (a commercial product manufactured by Florrisant Laboratory in the Netherlands, containing aluminum sulphate and a wetting agent) at a concentration of 10000 ppm for 4 hours.

3- Florrisant 600 at a concentration of 5000 ppm for 4 hours.

4- $\mathrm{GA}_{3}$ at a concentration of $20 \mathrm{ppm}$ for 24 hours.

5- Kinetin at a concentration of $25 \mathrm{ppm}+8$-Hydroxyquinoline (8-HQ) at $150 \mathrm{ppm}$ for 24 hours.

6- Sucrose at a concentration of $2 \%+\mathrm{AgNO}_{3}$ at $1000 \mathrm{ppm}$ for 30 minutes.

7- $\mathrm{AgNO}_{3}$ at a concentration of $1000 \mathrm{ppm}$ for 30 minutes.

After receiving the above-mentioned pulsing treatments, the flowers were bunched (3 flowers/ bunch), wrapped in cellophane sheets (as recommended by Jothi and Balakrishnamoorthy, 1999), and packed in 3 cardboard boxes (20 X 40 X $100 \mathrm{~cm})$, each representing a replicate of the treatments. The boxes were stored at a temperature of $2^{\circ} \mathrm{C}$ and a relative humidity (RH) of $85-90 \%$, in cold storage rooms at the Agricultural Development System Project (ADSP), Ministry of Agriculture, for periods of 7, 14, 21 or 28 days. Each box (replicate) contained 28 bunches, representing the different pulsing and storage period treatments ( 7 pulsing treatments X 4 storage periods). At the end of each storage period treatment (i.e., every 7 days, until the end of the experiment), the boxes were opened, and 7 bunches (representing the different pulsing treatments) 
were taken out of each box. The boxes were then re-closed and returned to cold storage.

This experiment was factorial ( 7 pulsing treatments $\times 4$ storage period treatments), conducted using a randomized complete blocks design with three replicates. The data collected in both seasons were subjected to a statistical analysis of variance (ANOVA), and the means were compared using the "Least Significant Difference (L.S.D.)" test at the 5\% level, as described by Little and Hills (1978).

The flower fresh weight was recorded at the beginning of the storage period, and at the end of each storage period (i.e., after 7, 14, 21 and 28 days). The rate of fresh weight loss was then calculated by subtraction, and division over the number of storage days, and the number of flowers weighed (3 flowers/ treatment/ replicate).

The respiration rate $(\mathrm{ml} \mathrm{CO} / \mathrm{kg} / \mathrm{hr})$ of the flowers were determined weekly during storage of the flowers, using a "Food Pack Gas Analyzer" (Sevomex Inst. Model 1450 C), according to Pesis and Ben-Arie (1984) and Lurie and Pesis (1992).

Also, at the end of the different storage period treatments $(7,14,21$ and 28 days), chemical analysis was conducted to determine the contents of total soluble sugars in fresh petals and leaves (according to Dubois et al., 1956), total soluble phenols in fresh petals and leaves (according to A.O.A.C., 1980), anthocyanins in fresh petals (according to Fuleki and Francis, 1968), as well as contents of total chlorophylls $(\mathrm{a}+\mathrm{b})$ in fresh leaves, and carotenoids in fresh leaves and petals (according to Nornai, 1982).

\section{RESULTS AND DISCUSSION}

\section{1- The rate of flowers fresh weight loss:}

Regarding the effect of pulsing solutions on the rate of fresh weight loss of rose flowers cv. First Red, regardless of the effect of storage periods, the data presented in Table 1 showed that, in both seasons, the rate of fresh weight loss was significantly decreased as a result of pulsing flowers with most of the pulsing solutions, as compared to pulsing with distilled water. The only exception to this tend was recorded in the first season with flowers treated with $1000 \mathrm{ppm}$ Florrissant 600 for $4 \mathrm{hrs}$ which lost significantly more weight (106.15 mg/day/flower) as compared to the other tested treatments, including the control. In the second season, pulsing the flowers in distilled water (control) for 30 minutes resulted in a significantly higher fresh weight loss $(127.38 \mathrm{mg} /$ day/flower $)$ as compared to the tested treatments. On the other hand, in both seasons, pulsing the flowers in a solution containing $25 \mathrm{ppm}$ kinetin $+150 \mathrm{ppm} 8$-HQ for 24 hours was the best treatment because it resulted in a significantly lower weight loss (43.98 and $54.35 \mathrm{mg} /$ day/flower in both seasons, respectively) as compared to any other treatment, followed by pulsing with $20 \mathrm{ppm}$ $\mathrm{GA}_{3}+150 \mathrm{ppm} 8$-HQ for 24 hours. These results are in agreement with the findings of Shiva and Bhattacharjee (2003) on Rosa hybrida cv. Raktagandha, who reported that kinetin increased water uptake and delayed wilting of petals. Also, Bhattacharjee 
(2000) reported that each of kinetin at 1, 2.5, 5, 10 and $25 \mathrm{ppm}$ and GA [gibberellic acid] at 50,100, 150, 200 and $250 \mathrm{ppm}$ had beneficial effects on water uptake and fresh weight of Eiffel Tower cut roses.

Concerning the effect of storage periods on the rate of fresh weight loss, the data showed that weight loss of rose flowers cv. First Red was significantly increased gradually with prolonging the storage period. Storing the flowers at $2^{\circ} \mathrm{C}$ for 28 days resulted in the maximum rate of reduction in flower weight (113.13 and 127.21 $\mathrm{mg} /$ day/flower in the first and second seasons, respectively). On the other hand, flowers stored for 7 days showed the minimum rate of reduction in fresh weight ( 28.87 and $37.11 \mathrm{mg} /$ day/flower in both seasons, respectively). The reduction in fresh weight of rose flowers cv. First Red may be due to the loss in moisture through transpiration and/or the consumption of the stored substances through respiration. These results are in agreement with the findings of Daj and Paul (1995) on Protea nerifolia cv. Pink Wink, and Vinod and Bhattacharjee (2004) on rose cv. Mercedes flowers. They reported that flower fresh weight decreased with increasing storage duration.

Regarding the interaction between the effects of pulsing solutions and storage periods, the data presented in Table (1) revealed that in both seasons, significant differences in the rate of fresh weight loss existed between flowers treated with different combinations of pulsing solutions and storage periods. Flowers pulsed with distilled water and stored for 28 days suffered the highest rate of flower weight reduction ( 153.70 and $176.90 \mathrm{mg} /$ day/flower in both seasons, respectively), whereas the lowest rate of flower weight loss $(20.40$ and $29.90 \mathrm{mg} /$ day/flower in the first and second seasons, respectively) was obtained in flowers pulsed with $25 \mathrm{ppm}$ kinetin + $150 \mathrm{ppm}$ 8-HQ for 24 hours and stored for 7 days. Moreover, among flowers that were stored for each of the different periods, those that had been pulsed in $25 \mathrm{ppm}$ kinetin $+150 \mathrm{ppm} 8$-HQ for 24 hours had the lowest rate of fresh weight loss, compared to all other pulsing treatments.

\section{2- The respiration rate of flowers:}

Data presented in Table 1 showed that in both seasons, the respiration rate of rose flowers was significantly decreased by most of the tested pulsing solutions, compared to pulsing with distilled water. Only one exception to this general trend was recorded in both seasons with flowers pulsed in $2 \%$ Sucrose $+1000 \mathrm{ppm} \mathrm{AgNO}_{3}$ for 30 minutes having a significantly higher respiration rate $(10.72$ and $12.98 \mathrm{ml}$ $\mathrm{CO}_{2} / \mathrm{kg} / \mathrm{hr}$ in the first and second seasons, respectively) than those of flowers receiving all other tested treatments, regardless of the effect of storage periods. This result is in agreement with the findings of Monteiro et al. (2001) on miniature rose, who reported that infusion of exogenous sucrose increased flower respiration rates. On the other hand, the lowest respiration rates recorded in the two seasons ( 7.85 and $7.83 \mathrm{ml} \mathrm{CO} / \mathrm{kg}$ in the first and second seasons, respectively) were those of flowers pulsed with $25 \mathrm{ppm}$ kinetin $+150 \mathrm{ppm}$ 8-HQ for 24 hours. Similar results were obtained by William (1977) on Dianthus caryophyllus cv. Peterson Red, who reported 
that a decrease in the respiration rate of flowers was recorded as a result of treating with cytokinins.

Regarding the effect of storage periods on the respiration rate of rose flowers cv. First Red, regardless of the effect of pulsing solutions, data in Table 1 showed that the respiration rate was significantly decreased with prolonging the storage periods (in most cases). Accordingly, the lowest respiration rate in both seasons was achieved after 28 days of storage. In this respect, Bhattacharjee (2000) on Raktagandha roses flowers and, Palanikumar et al. (2000) on rose flower, mentioned that the respiration rate became lower as storage time increased.

The respiration rate of rose flowers was significantly affected by the interaction between pulsing solutions and storage periods. Data in Table (1) showed that, in both seasons, the highest respiration rate of the flowers was recorded with flowers pulsed with distilled water and stored for 7 days. On the other hand, flowers treated with 25 ppm kinetin +150 ppm 8-HQ for 24 hours and stored for 28 days had the lowest respiration rate (in both seasons). The favourable effect of pulsing the flowers in $25 \mathrm{ppm}$ kinetin $+150 \mathrm{ppm} 8$-HQ for 24 hours was also clear within each of the four tested storage periods, i.e. in both seasons, flowers stored for the different storage periods had the lowest respiration rate when they had been pretreated with 25 ppm kinetin +150 ppm 8-HQ for 24 hours, compared to all other tested pretreatments. There was no significant difference between the respiration rate of flowers treated with 25 ppm kinetin +150 ppm 8-HQ for 24 hours and stored for 14 days and that of flowers treated with $25 \mathrm{ppm}$ kinetin $+150 \mathrm{ppm} 8$-HQ for 24 hours and stored for 28 days (which was the lowest rate recorded in each season). This result may be explained by the fact that kinetin slows down processes associated with both senescence and stress, and helps in maintaining petal turgidity for an extended period, as reported by Knee (2000) on Rosa hybrida cv. Classy, reported that stem respiration was inhibited by hydroxyquinoline.

\section{3- Total soluble sugars content:}

\section{a- Total soluble sugars content in the petals of rose flowers:}

Concerning the effect of pulsing solutions on the total soluble sugars content in the petals of rose flowers cv. First Red, regardless of the effect of storage periods, data in Table 2 indicated that, in most cases, pulsing flowers with different pulsing solutions increased the total soluble sugars content in petals, in both seasons, compared to that of flowers pulsed with distilled water. Two exceptions to this trend were recoded in both seasons with flowers pulsed with 5000 ppm Florrissant 600 for 4 hours or $1000 \mathrm{ppm} \mathrm{AgNO}_{3}$ for 30 min which gave a lower total soluble sugars content, as compared to that of flowers pulsed with distilled water. Among the different pretreatments, pulsing of Rosa hybrida flowers with 2\% Sucrose +1000 ppm $\mathrm{AgNO}_{3}$ for 30 minutes gave significantly higher total soluble sugars contents (1.78 and $2.12 \mathrm{~g} / 100 \mathrm{~g}$ fresh weight in the first and second seasons, respectively), compared to the other treatments (in most cases), followed by placing the flowers in a solution containing $20 \mathrm{ppm} \mathrm{GA} 3+150 \mathrm{ppm} 8$-HQ for 24 hours (which gave values of 1.51 and $2.01 \mathrm{~g} / 100 \mathrm{~g}$ in the two seasons, respectively), then placing the flowers in 25 
BADAWY ET AL 
ppm kinetin +150 ppm 8-HQ for 24 hours (giving 1.37 and $1.81 \mathrm{~g} / 100 \mathrm{~g}$ fresh weight in the two seasons, respectively). It is worth mentioning that using a pulsing solution containing $\mathrm{AgNO}_{3}$ only gave significantly lower total soluble sugars in the petals ( 1.10 and $1.13 \mathrm{~g} / 100 \mathrm{~g}$ fresh weight in the two seasons, respectively) than using $\mathrm{AgNO}_{3}+$ sucrose, and this may be explained by the important role played by sucrose as essential materials for carbohydrate metabolism in flower growth, development and for extending vase life, as reported by Kim and Lee (2002) on rose flowers cv. First Red.

Regarding the effect of storage periods on the total soluble sugars content in the petals, regardless of the effect of pulsing solutions, the data recorded in Table 2 indicated that, in both seasons, total soluble sugars content in the petals significantly decreased with prolonging storage periods (in most cases). Flowers of Rosa hybrida cv. First Red which were stored for 7 and 14 days had significantly higher contents of total soluble sugars $(1.58$ and $1.42 \mathrm{~g} / 100 \mathrm{~g}$ fresh weight, respectively, in the first season, and 2.06 and $1.87 \mathrm{~g} / 100 \mathrm{gm}$ fresh weight, respectively, in the second season), compared to values recorded after longer storage periods, with no significant difference between them in the first season. On the other hand, the flowers stored for 28 days gave significantly lower mean values $(0.99$ and $0.95 \mathrm{~g} / 100 \mathrm{~g}$ fresh weight in both seasons, respectively). The reduction in total soluble sugars during storage may be due to the respiration processes which involve a high consumption of simple sugars and other degradation processes which are intensified with prolonging the storage period. These results are in agreement with those obtained by Mwangi et al. (2003) on rose cv. Golden Gate, and Singh et al. (2004) on rose cv. Queen Elizabeth.

No significant interaction was detected between effects of pulsing solutions and storage periods on the content of total soluble sugars. Pulsing the flowers in a

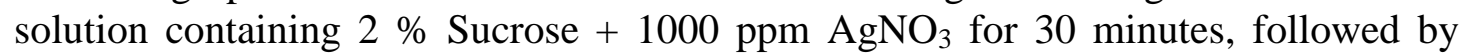
cold storage for 7 days, resulted in the highest content of total soluble sugars in the petals (2.04 and $2.58 \mathrm{~g} / 100 \mathrm{~g}$ fresh weight in the first and second seasons, respectively). In contrast, the lowest values $(0.54$ and $0.34 \mathrm{~g} / 100 \mathrm{~g}$ fresh weight in the two seasons, respectively) were recorded in petals of flowers pulsed in distilled water and stored for 28 days.

\section{b- Total soluble sugars in the leaves:}

Data presented in Table 2 showed that, in the first season, all pulsing solutions gave higher total soluble sugars content in leaves of rose flowers compared to the values recorded in flowers pulsed with distilled water. However, the differences between the total soluble sugars contents in leaves of flowers pulsed in the tested solutions (including distilled water) were statistically insignificant. On the other hand, the favourable effect of the pulsing solutions was more pronounced in the second season, as all pulsing solutions significantly increased total soluble sugars content in leaves of flowers, compared to the flowers pulsed with distilled water. In the second season, only one exception to this trend was recorded, with pulsing in $5000 \mathrm{ppm}$ Florrissant 600 for 4 hours giving an insignificantly higher total soluble sugars content in leaves, compared to pulsing in distilled water. Pulsing the flowers in 25 
ppm kinetin +150 ppm 8-HQ for 24 hours gave the highest total soluble sugars contents (1.11 and $1.89 \mathrm{~g} / 100 \mathrm{~g}$ fresh weight in the first and second seasons, respectively), compared to all other tested treatments, followed by pulsing in $20 \mathrm{ppm}$ $\mathrm{GA}_{3}+150 \mathrm{ppm} 8$-HQ for 24 hours $(1.08$ and $1.55 \mathrm{~g} / 100 \mathrm{~g}$ fresh weight in the two seasons, respectively), with values obtained with these two treatments being significantly different in the second season. On the other hand, pulsing the flowers in distilled water (control) gave the lowest values $(0.85$ and $0.88 \mathrm{~g} / 100 \mathrm{~g}$ fresh weight in the two seasons, respectively).

Data in Table 2, also show that, in both seasons, the total soluble sugars content in the leaves was significantly decreased by prolonging the storage period. Accordingly, the highest mean values (1.32 and $1.94 \mathrm{~g} / 100 \mathrm{~g}$ fresh weight in the first and second seasons, respectively) were recorded for flowers stored for 7 days, whereas flowers stored for 28 days had the lowest total soluble sugars content in the leaves. These results are in agreement with those reported by Jones (1995) on Leucadendron cv. Silver Red, and Singh and Bhattacharjee (1999) on cut Raktagandha roses, who found that the total soluble sugars content in leaf tissue declined with prolonging storage periods.

The interaction between the effects of pulsing solutions and storage periods on the total soluble sugars content was significant in the second season only (Table 2). Data presented in Table 2 show that in both seasons, flowers pulsed with distilled water and stored for 28 days had the lowest total soluble sugars content in their leaves ( 0.44 and $0.34 \mathrm{~g} / 100 \mathrm{~g}$ fresh weight in the first and second seasons, respectively). On the other hand, in the first season, the highest total soluble sugars in leaves (1.48 $\mathrm{g} / 100 \mathrm{~g}$ fresh weight) was obtained from flowers stored for 7 days and pulsed with 20 ppm $\mathrm{GA}_{3}+150$ ppm 8-HQ for 24 hours. In the second season, flowers pulsed with 25 ppm kinetin $+150 \mathrm{ppm} 8$-HQ for 24 hours and stored for 7 days gave the highest total soluble sugars content in leaves $(2.87 \mathrm{~g} / 100 \mathrm{~g}$ fresh weight). This means that kinetin and $\mathrm{GA}_{3}$ were more effective in raising the content of total soluble sugars in leaves as compared with most of the other tested treatments (within each of the different storage periods). In general, it is worth mentioning that, in both seasons, there was no significant difference between the total soluble sugars contents in leaves of flowers pulsed in $25 \mathrm{ppm}$ kinetin $+150 \mathrm{ppm}$ 8-HQ for 24 hours and stored for 14 days and the highest recorded values. This means that no other treatment combination gave significantly higher total soluble sugars contents, than pulsing in $25 \mathrm{ppm}$ kinetin + $150 \mathrm{ppm}$ 8-HQ for 24 hours, followed by storing the flowers for 14 days. This is in harmony with data collected on other physiological characteristics, which showed the superior effect of this treatment combination (as previously discussed).

In most cases, rose petals had higher total soluble sugars contents than leaves. Similar result was recorded by De et al. (1996) on Rosa hybrida cv. Super Star and Kim et al. (2005 b) on Iris hollandica. 


\section{4- Total soluble phenols content:}

\section{a- Total soluble phenols content in the petals:}

Concerning the effect of pulsing solutions on the content of the total soluble phenols in the petals of rose flowers, regardless of the effect of storage periods, data presented in Table 3 revealed that in both seasons, flowers pulsed with distilled water had significantly lower total soluble phenols contents in petals $(3.71$ and $5.96 \mathrm{mg} / \mathrm{g}$ fresh weight in the first and second seasons, respectively), compared to the other pulsing treatments (in most cases). On the other hand, flowers pulsed with $25 \mathrm{ppm}$ kinetin $+150 \mathrm{ppm} 8$-HQ for 24 hours had significantly higher phenols content in their petals in both seasons $(5.28$ and $11.77 \mathrm{mg} / \mathrm{g}$ fresh weight in the first and second seasons, respectively), compared to any other pulsing treatment.

Concerning the effect of storage periods on the content of total soluble phenols content in the petals of rose flowers, regardless of the effect of pulsing solutions, the data presented in Table 3 revealed that, in both seasons, the total soluble phenols content in the petals was significantly increased with prolonging storage period (in most cases). In most cases, storage of Rosa hybrida cv. First Red flowers for 28 days gave significantly higher contents of total soluble phenols in the petals (4.62 and 9.44 $\mathrm{mg} / \mathrm{g}$ fresh weight in the first and second seasons, respectively), compared to other storage periods. In both seasons, storage of the flowers for 7 days gave significantly lower contents of total soluble phenols $(4.01$ and $7.70 \mathrm{mg} / \mathrm{g}$ fresh weight in both seasons, respectively), compared to the other storage periods. These results are in agreement with those obtained by Mwangi et al. (2003) on cut rose flowers cv. Golden Gate, who reported that prolonging storage periods was associated with high total soluble phenols contents, and that prolonged vase life was associated with high total soluble phenols concentration.

The total soluble phenols content in the petals was not significantly influenced by interaction between effects of pulsing solutions and storage periods (in both seasons). Flowers pulsed with $25 \mathrm{ppm}$ kinetin $+150 \mathrm{ppm} 8$-HQ for 24 hours and stored for 28 days had the highest total soluble phenols content in their petals (5.63 and $12.80 \mathrm{mg} / \mathrm{g}$ fresh weight in the two seasons, respectively), compared to flowers treated with any other combination of pulsing treatments and storage periods. In contrast, flowers pulsed in distilled water and stored for 7 days had the lowest total soluble phenols content (3.39 and $5.03 \mathrm{mg} / \mathrm{g}$ fresh weight in the both seasons, respectively).

\section{b-Total soluble phenols content in the leaves :}

Concerning the effect of pulsing solutions on the total soluble phenols content in the leaves of rose flowers, it was evident from the data in Table 3 that in both seasons, all pulsing solutions increased total soluble phenols content in leaves, compared to pulsing in distilled water. Only exception to this trend was recorded in both seasons, with flowers pulsed in 5000 ppm Florrissant 600 for 4 hours resulting in an insignificantly lower total soluble phenols in leaves, compared to that obtained in flowers pulsed with distilled water. In most cases, pulsing rose flowers in $25 \mathrm{ppm}$ kinetin $+150 \mathrm{ppm} 8$-HQ for 24 hours resulted in significantly higher total soluble 
BADAWY ET AL 
phenols contents $(3.86$ and $4.34 \mathrm{mg} / \mathrm{g}$ fresh weight in the first and second seasons, respectively), compared to the other pulsing solutions.

Regarding the effect of storage periods on the total soluble phenols content in the leaves, regardless of the effect of pulsing solutions, the data presented in Table (3) indicated that the total soluble phenols content was increased steadily in both seasons as a result of prolonging the storage period. However, there was no significant difference between the total soluble phenols contents recorded after different storage periods in the first season. In general, Rosa hybrida cv. First Red flowers which were stored at $2^{\circ} \mathrm{C}$ for 28 days had the highest content of total soluble phenols in the leaves ( 3.69 and $3.93 \mathrm{mg} / \mathrm{g}$ fresh weight in the first and second seasons, respectively), whereas storage for 7 days gave the lowest values $(3.23$ and $2.97 \mathrm{mg} / \mathrm{g}$ fresh weight in the two seasons, respectively).

The total soluble phenols content in leaves of rose flowers was not significantly influenced by the interaction between effects of pulsing solutions and storage periods (in both seasons). Dipping flowers in $25 \mathrm{ppm}$ kinetin $+150 \mathrm{ppm} 8$-HQ for 24 hours, then storing them for 28 days resulted in the highest total soluble phenols content $(4.16$ and $4.90 \mathrm{mg} / \mathrm{g}$ fresh weight in the first and second seasons, respectively). The lowest contents $(3.00$ and $1.80 \mathrm{mg} / \mathrm{g}$ fresh weight in the two seasons, respectively) were recorded in the leaves of rose flowers pulsed in a solution containing $5000 \mathrm{ppm}$ Florrissant 600 for 4 hours, then stored for 7 days at $2^{\circ} \mathrm{C}$.

In general, rose petals had higher contents of total soluble phenols than the leaves (regardless of the treatment). This result is in agreement with the findings of Kim et al. (2005 a) on Lilium spp. flowers.

\section{5- Pigments content in the petals:}

a- Anthocyanins content in the petals:

Regarding the effect of pulsing solutions on anthocyanins contents in the petals of rose flowers, data presented in Table 4 revealed that, regardless of the effect of storage periods, all the tested pulsing solutions significantly increased the anthocyanins content in petals, compared to that of flowers pulsed with distilled water. Two exceptions to this general trend were recorded in the first season, with flowers pulsed in 5000 or 10000 ppm Florrissant 600 for 4 hours having insignificantly higher anthocyanins contents than flowers pulsed in distilled water. Among the different pulsing treatments, pulsing the flowers in a solution containing 25 ppm kinetin +150 ppm 8-HQ for 24 hours gave significantly higher contents of anthocyanins ( 0.60 and $1.42 \mathrm{~g} / 100 \mathrm{~g}$ fresh weight in the two seasons, respectively) than most of the other pulsing treatments. It was evident that kinetin may play a role in maintaining the anthocyanins content in the petals, as reported by Vaknin et al. (2005) on Brunfelsia calycina. The flowers pulsed with distilled water gave the lowest anthocyanins content $(0.27$ and $0.38 \mathrm{~g} / 100 \mathrm{~g}$ fresh weight in the two seasons, respectively).

It is also obvious from the data in Table 4 that the anthocyanins content in the petals of rose flowers decreased with prolonging the storage periods. This result is in agreement with the findings of Byun et al. (2000) on Dianthus caryophyllus cvs. 
BADAWY ET AL 
Desio and Fillandero, who found that the anthocyanins content in flowers decreased with prolonging the storage period. In most cases, flowers stored for 7 days had significantly higher anthocyanin contents in petals $(0.50$ and $1.19 \mathrm{~g} / 100 \mathrm{~g}$ fresh weight in the first and second seasons, respectively), compared to the values recorded in petals of flowers stored for longer storage periods. In the first season, there was no significant difference between the anthocyanins content in petals of flowers stored for 7 and 14 days.

The data in Table 4 show that the anthocyanins content was significantly affected by the interaction between effects of pulsing solutions and storage periods. Flowers pulsed in a solution containing 25 ppm kinetin +150 ppm 8-HQ for 24 hours and stored for 7 days had the highest anthocyanins content in petals $(0.73$ and $1.88 \mathrm{~g} /$ $100 \mathrm{~g}$ fresh weight in the first and second seasons, respectively). In both seasons, there was no significant difference between the anthocyanins content of flowers pulsed with 25 ppm kinetin +150 ppm 8-HQ for 24 hours and stored for 7 days, and that of flowers treated with the same pulsing solution and stored for 14 days. On the other hand, the lowest anthocyanins content $(0.17$ and $0.26 \mathrm{~g} / 100 \mathrm{~g}$ fresh weight in the two seasons, respectively) was recorded in flowers pulsed with distilled water and stored for 28 days.

\section{b-Carotenoids content in the petals:}

Data presented in Table 4 indicated that, in both seasons, petals of flowers pulsed in the tested solutions had significantly higher carotenoids contents, as compared petals of flowers pulsed in distilled water. In the first season, flowers pulsed in a solution containing 2\% Sucrose $+1000 \mathrm{ppm} \mathrm{AgNO}_{3}$ for 30 minutes gave the highest carotenoids content in petals $(40.44 \mathrm{mg} / 100 \mathrm{~g}$ fresh weight) followed by flowers pulsed in $25 \mathrm{ppm}$ kinetin $+150 \mathrm{ppm} 8$-HQ for 24 hours $(39.66 \mathrm{mg} / 100 \mathrm{~g}$ fresh weight), with no significant difference between them. These two treatments gave significantly higher carotenoids contents in petals compared to any other treatment (in the first season). In the second season, flowers pulsed in $25 \mathrm{ppm}$ kinetin $+150 \mathrm{ppm} 8$ HQ for 24 hours had a significantly higher content of carotenoids $(67.18 \mathrm{mg} / 100 \mathrm{~g}$ fresh weight) compared to that of flowers pulsed in any other pulsing solution. It is clear from the presented data that, in both seasons, using a pulsing solution containing kinetin significantly reduced carotenoids loss compared with all other tested solutions. Similar results were reported by Garcia-Luis et al. (1986) on Satsuma mandarin, who noted that kinetin played an important role in maintaining carotenoids content against the oxidation and inhibition caused by some biosynthetic pathways. Flowers treated with distilled water had a significantly lower content of carotenoids (21.91 and 33.11 $\mathrm{mg} / 100 \mathrm{~g}$ fresh weight in the first and second seasons, respectively) than those receiving any other pulsing treatment.

It is clear from data in Table 4 that the carotenoids content in petals of rose flowers was significantly decreased with increasing storage periods, regardless of the effect of pulsing solutions. In the two seasons, storing flowers for 7 days gave significantly higher contents of carotenoids $(39.54$ and $56.25 \mathrm{mg} / 100 \mathrm{~g}$ fresh weight in the first and second seasons, respectively), compared with all other storage periods. 
On the other hand, the lowest carotenoids content $(26.80$ and $41.14 \mathrm{mg} / 100 \mathrm{~g}$ fresh weight, in the first and second seasons, respectively) was recorded at the end of the longest storage period (28 days). These results are in agreement with the findings of Byun et al. (2000) on Dianthus caryophyllus cvs. Desio and Fillandero.

The carotenoids content in the petals of rose flowers was significantly affected by the interaction between effects of pulsing solutions and storage periods. In the first season, the highest carotenoids content $(51.17 \mathrm{mg} / 100 \mathrm{~g}$ fresh weight) was recorded in flowers pulsed with $2 \%$ Sucrose +1000 ppm $\mathrm{AgNO}_{3}$ for 30 minutes and stored for 7 days. Flowers pulsed with 25 ppm kinetin +150 ppm 8-HQ for 24 hours and stored for 7 or 14 days had carotenoids contents $(50.28$ and $46.98 \mathrm{mg} / 100 \mathrm{~g}$ fresh weight, respectively) that were not significantly lower than the highest carotenoids content recorded in the first season. In the second season, flowers pulsed with 25 ppm kinetin $+150 \mathrm{ppm} 8$-HQ for 24 hours and stored for 7 days gave the highest carotenoids content $(73.00 \mathrm{mg} / 100 \mathrm{~g}$ fresh weight). On the other hand the lowest carotenoids content in petals $(18.62$ and $25.34 \mathrm{mg} / 100 \mathrm{~g}$ fresh weight in the first and second seasons, respectively) was recorded in flowers pulsed with distilled water for 30 minutes and stored for 28 days.

\section{6- Pigments content in the leaves: a- Total chlorophylls $(a+b)$ content:}

Regarding the effect of pulsing solutions on total chlorophylls $(a+b)$ contents in the leaves of rose flowers, data presented in Table 5 revealed that, in both seasons, most of pulsing solutions significantly increased the total chlorophylls content in the leaves of rose flowers, as compared to pulsing in distilled water, regardless of the storage periods. Similar result was reported by Hassan and Schmidt (2004) on Dianthus caryophyllus cv. Asso, who found that pretreatment with different chemicals resulted in a higher chlorophyll content in the leaves than the control (distilled water). Only one exception to this general trend was recorded in the first season, with flowers pulsed using 10000 ppm Florrissant 600 for 4 hours having an insignificantly higher total chlorophylls content, as compared to that of flowers pulsed in distilled water. The highest total chlorophylls content (104.58 and $107.00 \mathrm{mg} / 100 \mathrm{~g}$ fresh weight in the two seasons, respectively) was recorded in the leaves of flowers pulsed in a solution containing 20 ppm $\mathrm{GA}_{3}+150 \mathrm{ppm} 8$-HQ for 24 hours, as compared to the values recorded after pulsing with other solutions. These results are in agreement with the findings of Cai et al. (2000) on cut Rosa hybrida, Ichimura and Goto (2002) on Narcissus tazetta cv. Chinensis, and Hettiarachchi and Balas (2003) on Codiaeum variegatum $\mathrm{cv}$. Excellent, who reported that $\mathrm{GA}_{3}$ and 8-HQ retarded the total loss in leaf chlorophyll content and increased chlorophyll retention. The leaves of flowers pulsed with distilled water had the lowest total chlorophylls content (77.19 and 76.64 $\mathrm{mg} / 100 \mathrm{~g}$ fresh weight in the first and second seasons, respectively).

It is obvious from the data in Table 5 that in both seasons, the total chlorophylls content in the leaves of rose flowers was significantly decreased with prolonging the storage periods (in most cases). The flowers stored for 7 days had significantly higher total chlorophylls contents in leaves (102.40 and $103.55 \mathrm{mg} / 100$ 
$\mathrm{g}$ fresh weight in the first and second seasons, respectively), as compared to longer storage periods. In contrast, the lowest total chlorophylls content was recorded in leaves of flowers stored for 28 days. These results are in agreement with the findings of Byun et al. (2000) on Dianthus caryophyllus cvs. Desio and Fillandero and Singh and Kumar (2000) on Phyllanthus emblica cv. Chakaiya, who found that the chlorophyll content in leaves decreased with increasing the storage period.

The data in Table 5 showed that, in both seasons, the total chlorophylls content in leaves of rose flowers was significantly affected by the interaction between effects of pulsing solutions and storage periods. In the first season, flowers pulsed in a solution containing $20 \mathrm{ppm} \mathrm{GA}_{3}+150 \mathrm{ppm} 8$-HQ for 24 hours and stored for 7 days had the highest total chlorophylls content (116.71 mg/ $100 \mathrm{~g}$ fresh weight). Also, it is worth mentioning that the total chlorophylls content in the leaves of flowers pulsed with 25 ppm kinetin +150 ppm 8-HQ for 24 hours and stored for 14 days gave insignificantly lower value than the highest value recorded. These results are in agreement with the findings of Janowska and Jerzy (2003) on Zantedeschia elliottiana cvs. Florex Gold and Black Magic, and Emongor and Tshwenyane (2004) on Lilium longiflorum, who reported that the gibberellic acid and cytokinin limited the degradation of chlorophyll. In the second season, the flowers pulsed in a solution containing 25 ppm kinetin +150 ppm 8-HQ for 24 hour and stored for 7 days gave the highest total chlorophylls content $(122.80 \mathrm{mg} / 100 \mathrm{~g}$ fresh weight). On the other hand, the lowest chlorophylls contents $(64.33$ and $65.45 \mathrm{mg} / 100 \mathrm{~g}$ fresh weight in the first and second seasons, respectively) were recorded in leaves of flowers pulsed with distilled water and stored for 28 days.

\section{b-Carotenoids content:}

Data presented in Table 5 indicated that, in both seasons, pulsing flowers in any of the tested pulsing solutions significantly increased the carotenoids content in leaves, compared to pulsing in distilled water. In the first season, pulsing rose flowers with $25 \mathrm{ppm}$ kinentin $+150 \mathrm{ppm} 8$-HQ for 24 hours gave a significantly higher carotenoids content $(41.02 \mathrm{mg} / 100 \mathrm{~g}$ fresh weight) than any other pulsing treatment, while in the second season, flowers pulsed with $20 \mathrm{ppm} \mathrm{GA}_{3}+150 \mathrm{ppm}$ 8-HQ for 24 hours gave a significantly higher carotenoids content $(45.47 \mathrm{mg} / 100 \mathrm{~g}$ fresh weight), compared with all other tested treatments. On the other hand, the lowest carotenoids contents (19.48 and $25.13 \mathrm{mg} / 100 \mathrm{~g}$ fresh weight in the first and second seasons, respectively) were found in the leaves of flowers pulsed in distilled water.

Regarding the effect of storage periods on carotenoids content in the leaves of rose flowers, data presented in Table 5 revealed that in both seasons, the carotenoids content in leaves of rose flowers was significantly decreased with prolonging storage periods, regardless of the effect of pulsing solutions. Flowers stored for 7 days had significantly higher carotenoids contents $(35.82$ and $41.81 \mathrm{mg} / 100 \mathrm{~g}$ fresh weight in the first and second seasons, respectively), compared to those recorded after longer storage periods. On the other hand, storage of the flowers for 28 day resulted in the lowest carotenoids contents (21.85 and $23.40 \mathrm{mg} / 100 \mathrm{~g}$ in the two seasons, respectively). 
The data in Table 5 show that the carotenoids content in the leaves was significantly affected by the interaction between the effects of pulsing solutions and storage periods. In the first season, flowers pulsed in a solution containing $25 \mathrm{ppm}$ kinetin $+150 \mathrm{ppm} 8$-HQ for 24 hours and stored for 7 days had the highest carotenoids content in the first season $(48.75 \mathrm{mg} / 100 \mathrm{~g}$ fresh weight), followed by flowers pulsed in the same solution ( 25 ppm kinetin + 150 ppm 8-HQ for 24 hours) and stored for 14 days, which had an insignificantly lower carotenoids content. In the second season, the highest value $(53.90 \mathrm{mg} / 100 \mathrm{~g}$ fresh weight) was recorded in leaves of flowers pulsed in a solution containing $20 \mathrm{ppm} \mathrm{GA}_{3}+150 \mathrm{ppm}$ 8-HQ for 24 hours and stored for 7 days. On the other hand, flowers pulsed in distilled water and stored for 28 days had the lowest carotenoids contents $(12.20$ and $13.90 \mathrm{mg} / 100 \mathrm{~g}$ fresh weight in first and second seasons, respectively), compared to all other treatment combinations.

Recommendation: From the above results, it is clear that flowers pulsed with 25 ppm kinetin +150 ppm 8-HQ for 24 hours and stored for 14 days gave an insignificantly different respiration rate compared to the lowest values, and gave total soluble sugars in petals and leaves, total soluble phenols in petals and leaves, anthocyanins and carotenoids in petals insignificantly different than the highest values recorded for each characteristic. Therefore, it can be recommended that Rosa hybrida cv. First Red should be pulsed in 25 ppm kinetin +150 ppm 8-HQ for 24 hours, then stored for 14 days at a temperature of $2^{\circ} \mathrm{C}$ and a relative humidity of $85-90 \%$. This helps to maintain good physiological characteristics and chemical constituents of flowers.

\section{REFERENCES}

A.O.A.C (1980). Association of Official Analytical Chemists. Official Methods of Analysis. 832-849 Washington. D.C., USA.

Bhattacharjee, S. K. (2000). Postharvest life of "Eiffel Tower" cut roses and biochemical constituents of petal tissues as influenced by growth regulating chemicals in the holding solution. Haryana J. Hort. Sci., 29 (1/2): 66-68.

Bhattacharjee, S. K and L. C. De (1998). Influence of pulsing with different chemicals on postharvest life and biochemical constituents of cut roses. $P K V$ Research Journal, 22 (2): 183 - 187.

Byun, M.; C. K. Sang and K. W. Kim (2000). Flowering response of cut carnations harvested at various bud stages and stored at low temperature. J. Korean Soc. Hort. Sci., 41( 5): 531-534.

Cai ,Y. P.; S. Nie; H. Y. Zhang and H. X. Yu (2000). Influence of salicylic acid on vase life and physiological action of cut rose flower. Acta Horticulturae, 27 (3): $228-230$.

Daj, J. W. and R. E. Paul (1995). Source sink relationship and protea postharvest leaf blackening. J. Amer. Soc. Hort. Sci., 120 (3): 475 - 480. 
De, L. C.; S. R. Chatterjee; T. V. R. Nair and S. K. Bhattacharjee (1996). Influence of bud opening solutions on the biochemical changes occurring in cut roses of varying maturity. Plant Physiol. \& Biochem., 23 (2):173-178.

Dubois, M.; F. Smith; K. A. Gilles; J. K. Hamilton and P. A. Rebers (1956). Colorimetric method for determination of sugars and related substances. Annal. Chem., 28 (3): 350-356.

Eason, J. R.; E. R. Morgan; A. C. Mullan and G. K. Burge (2001). Postharvest characteristics of Sontonia cv. Golden Light a new hybrid cut flower from Sandersonia aurantiaca X Littonia modesta. Postharvest Biology and Technology, 22 (1): 93-97.

Emongor, V. and S. O. Tshwenyane (2004). Effect of Accel on the postharvest vase life of Easter lily. J. Agron., 3 (3): 170-174.

Ferrante, A.; S. A. Mensuali; G. Serra and F. Tognoni (1998). Ethylene production and vase life in cut Eucalyptus spp. foliage. Italus Hortus, 5 (5/6): 57-60.

Fuleki, T. and F. J. Francis (1968). Quantitative methods for anthocyanins extraction and determination of total anthocyanin in cranberries. J. Food Sci., 33: $72-77$.

Garcia-Luis, A.; F. Fornes and J. L. Guardiola (1986). Effects of gibberellin $\mathrm{GA}_{3}$ and cytokinins on natural and post-harvest, ethylene-induced pigmentation of Satsuma mandarin peel. Physiologia Plantarum, 68(2): 271-274.

Hassan, F. and G. Schmidt (2004). Post-harvest characteristics of cut carnations as the result of chemical treatments. Acta Agronomica Hungarica, 52(2):125132.

Hettiarachchi, M. P. and J. Balas (2003). Effects of hydration solutions on postharvest quality of croton (Codiaeum variegatum, L. A. Juss.cv, 'Excellent') after shipment. Tropical Agricultural Research, 15: 327-330.

Ichimura, K. and R. Goto (2002). Extension of vase life of cut Narcissus tazetta cv. Chinensis flowers by combined treatment with STS and gibberellin $\mathrm{A}_{3}$. J. Japanese Soc. Hort. Sci., 71(2): 226-230.

Janowska, B. and M. Jerzy (2003). Effect of gibberellic acid on post-harvest leaf longevity of Zantedeschia elliottiana (W. Wats.) Engl. J. Fruit and Ornamental Plant Research., 11: 69-76.

Jones, R. B. (1995). Sucrose prevents foliage desiccation in cut Leucadendron 'Silver Red' during cool storage. Postharvest Biology and Technol., 6 (3/4): 293-301.

Jothi, L. J. and G. Balakrishnamoorthy (1999). Effect of pulsing and packing materials on postharvest life of rose cv. Happiness. South Indian Horticulture, 47 (1/ 6): 361-363.

Kim J. H.; A. K. Lee and J. K. Suh (2005 a). Effect of certain pre-treatment substances on vase life and physiological character in Lilium spp. Acta Horticulturae, 673 (1): 307-314.

Kim, S. J.; C. W. Nam; J. T. Suh; D. L. Yoo and K. Kim (2005 b). Effects of pretreatment solutions on vase life, anthocyanin content, and peroxidase activity of Iris hollandica. Korean J. Hort. Sci. \& Technol., 23 (2): 223-229. 
Kim, Y. and J. Lee (2002). Changes in lignin content, phenylalanine ammonia lyase activity, and peroxidase activity as affected by bent neck and senescence of cut rose flowers. J. Korean Soc. Hort. Sci., 43 (2): 208-212.

Knee, M. (2000). Selection of biocides for use in floral preservatives. Postharvest Biology and Technology, 18 (3): 227-234.

Little, T. M. and F. J. Hills (1978). Agricultural Experimentation - Design and Analysis. John Wiley \& Sons, Inc., New York, USA, 53-63.

Lurie, S. and E. Pesis (1992). Effect of acetaldehyde and anaerobiosis as postharvest treatment on the quality of peaches and nectarines. Postharvest Biol. and Technol., 1: 317-326.

Monteiro, J. A.; T. A. Nell and J. E. Barrett (2001). Postproduction of potted miniature rose: flower respiration and single flower longevity. J. Amer. Soc. Hort. Sci., 126 (1): 134-139.

Mwangi, M.; S. R. Chatterjee and S. K. Bhattacharjee (2003). Changes in the biochemical constituents of 'Golden Gate' cut rose petals as affected by precooling with ice-cold water spray, pulsing and packaging. J. Plant Biology, 30 (1): 95-97.

Nornai, R. (1982). Formula for determination of chlorophyll pigments extracted with N.N. dimethyl formamide. Plant Physiol., 69: 1371-1381.

Palanikumar, S.; P. Madan and S. K. Bhattacharjee (2000). Influence of precooling on postharvest life and respiration rate of Raktagandha cut roses. Indian Plant Physiol., 5 (2): 203-204.

Pesis, E. and R. Ben-Arie (1984). Involvement of acetaldehyde and ethanol accumulation during induced deastringency of persimmon fruits. J. Food Sci., 49: 896-899.

Sacalis, J. (1993). Cut Flower Prolonging Freshness. Williams and Norgate Ltd., London, 14-15.

Serrano, M.; G. Martinez; M. T. Pretel; F. Riquelme and F. Romojaro (1992). Cold storage of rose flowers (Rosa hybrida cv. 'Visa'): physiological alterations. Scientia Horticulture, 51 (1-2): 129-137.

Shiva, K. N. and S. K. Bhattacharjee (2003). Effect of chemical preservatives on vase life of cut rose. South Indian Horticulture, 51(1/6): 232-236.

Singh, A. K.; P. J. Singh, and R. Kumar (2004). Effect of some chemicals on keeping quality of cut roses. Advances in Horticultural Science, 18 (4): 161167.

Singh, R. and S. Kumar (2000). Studies on the effect of post-harvest treatments on decay loss and biochemical changes during storage of aonla (Phyllanthus emblica cv. Chakaiya ). Haryana J. Hort. Sci. , 29 (3/4): 178-179.

Singh, U. C. and S. K. Bhattacharjee (1999). Changes in total soluble sugar and free amino acids in cut Raktagandha roses as influenced by pre-harvest spray of micronutrients. Indian J. Hill Farming, 12 (1/2): 37-41.

Sytsema, K. E. C. (1990). Post-harvest research on lilac (1). HQS improves water uptake.Vakblad voor de Bloemisterij, 45 (46): 68-69. 
Vaknin, H.; A. Bar-Akiva; R. Ovadia; A. Nissim-Levi; I. Forer; D. Weiss and M. Oren-Shamir (2005). Active anthocyanin degradation in Brunfelsia calycina (yesterday-today-tomorrow) flowers. Planta., 222 (1): 19-26.

Vinod, K. and S. K. Bhattacharjee (2004): Postharvest life and quality of "Mercedes" cut roses as influenced by pulsing with D-fructose + 8-HQC, Alar and dry cool storage. Scientific Horticulture, 9: 171-179.

Wawrzynczak, A. and D. M. Goszczynska (2003). Effect of pulse treatment with exogenous cytokinins on longevity and ethylene production in cut carnations (Dianthus caryophyllus L.). J. Fruit and Ornamental Plant Research, 11: 7788.

William (1977). Role of cytokinins in carnation flower senescence. Plant Physiol., 59: 707-709. 


\title{
تـأثير بعض محاليـل الغفس ومـدة التخزين البـارد على الصـفات الفسيولوجية

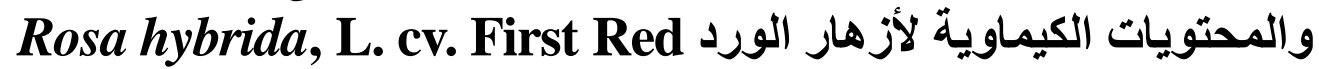

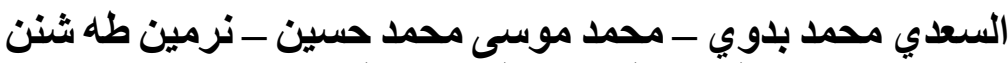

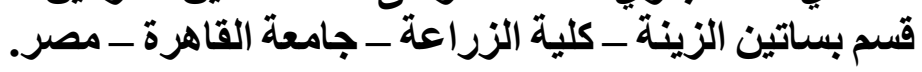

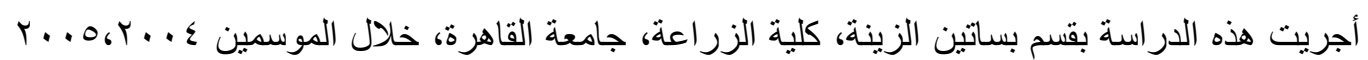

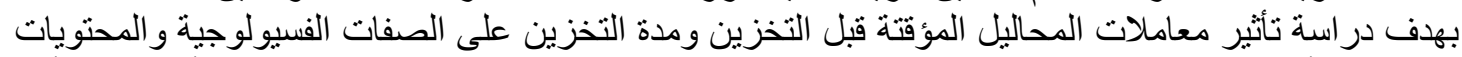

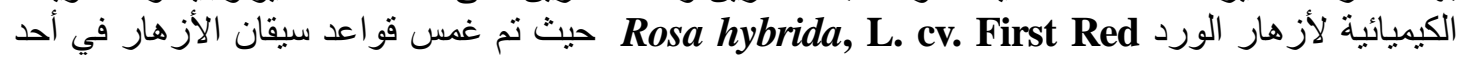

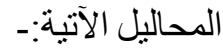

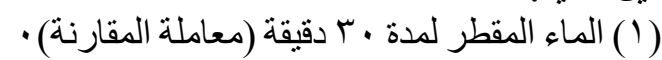

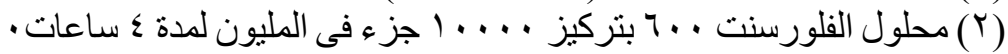

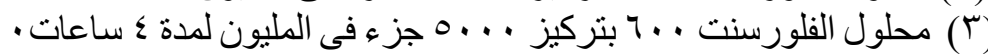

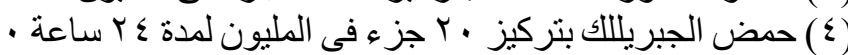

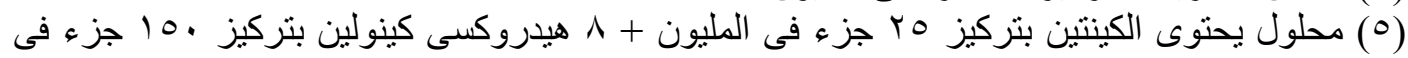

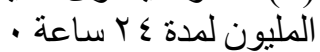

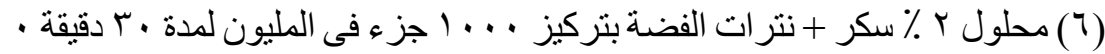

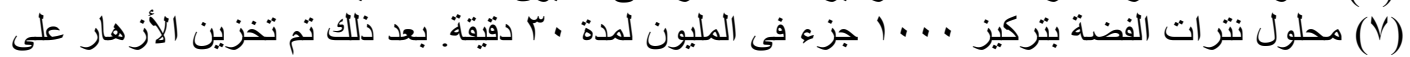

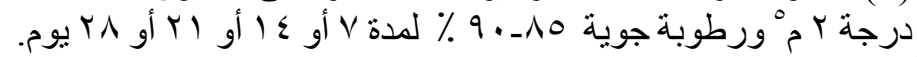

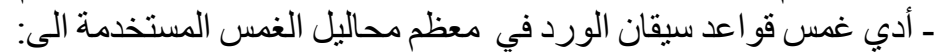

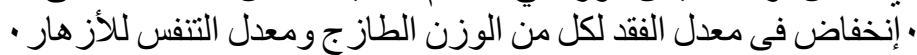

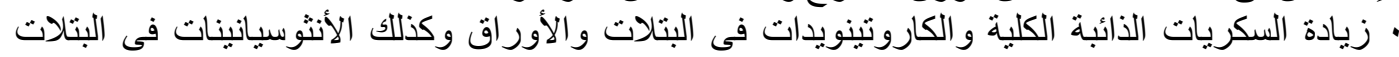

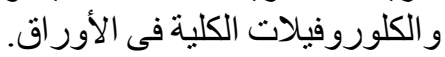

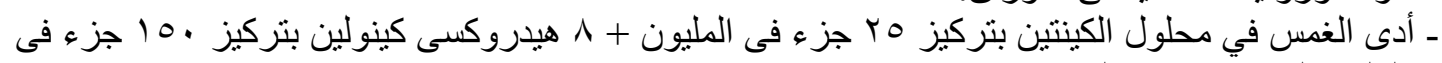

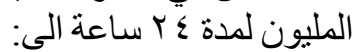

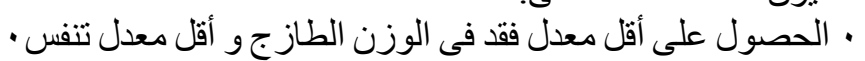

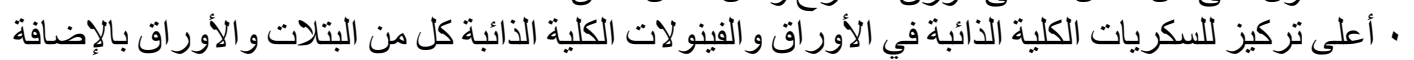

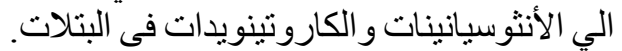

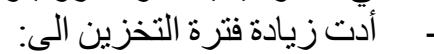

• ز زيادة معدل الفقد فى الوزن الطاز جل للأز هار وزيادة الفينو لات الكلية الذائبة فى البتلات و الأوراق •

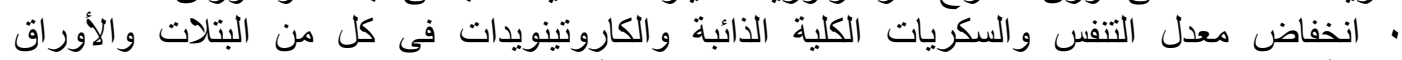

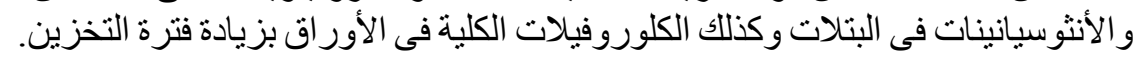

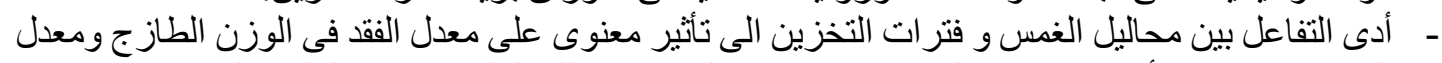

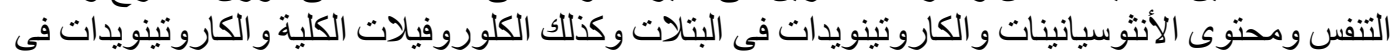

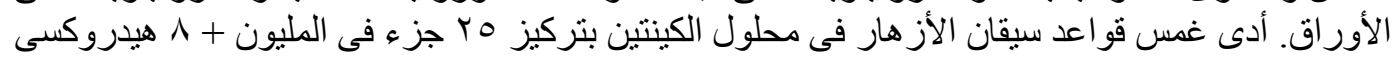

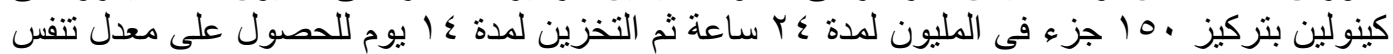

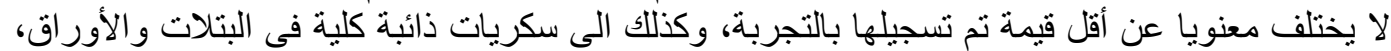

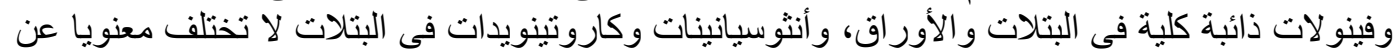

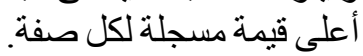

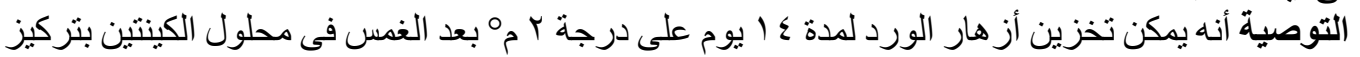

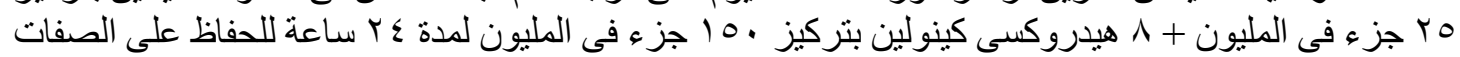
الفسيولوجية و المحتويات الكيميائية جيدة. 